\title{
Successful transfusion care for a patient with the Rhesus -D- phenotype and antibodies against Rh17 and two additional alloantibodies
}

\author{
Karen M. K. De Vooght • Ayșe Y. Demir • \\ Claudia C. Folman • Roger E. G. Schutgens • \\ Wouter W. van Solinge $\cdot$ Hans Kemperman
}

Received: 15 June 2011 / Accepted: 25 September 2011 /Published online: 6 October 2011

(C) The Author(s) 2011. This article is published with open access at Springerlink.com

\section{Dear Editor,}

In transfusion medicine, it can be a challenge to obtain compatible blood for patients who have clinically important alloantibodies to high-prevalence antigens. We describe a case which examples the decision process for autologous blood deposition in the Dutch health care system.

In September 2006, a 56-year-old man was admitted to the emergency room after a serious accident. Coagulation and hematology parameters were in normal range except for a low hemoglobin of $7.9 \mathrm{~g} / \mathrm{dL}$. His blood group was determined as O, Rhesus D-positive and antibody screening (DiaMed) was negative. Transfusion anamnesis was also negative. Two units of packed erythrocytes were administrated. Eight days later hemoglobin had dropped to $7.1 \mathrm{~g} / \mathrm{dL}$. Upon a negative antibody screening, 2 units of erythrocytes were transfused. After 20 days, the patient had to undergo surgery. Now, antibody screening

K. M. K. De Vooght $(\bowtie) \cdot$ W. W. van Solinge $\cdot H$. Kemperman Department of Clinical Chemistry and Haematology, University Medical Center Utrecht,

Postbus 85500,

3508 GA Utrecht, The Netherlands

e-mail: k.devooght@umcutrecht.nl

A. Y. Demir

Department of Clinical Chemistry and Haematology,

Meander Medical Center,

Amersfoort, The Netherlands

C. C. Folman

Sanquin Diagnostic Services,

Amsterdam, The Netherlands

R. E. G. Schutgens

Department of Haematology/Van Creveldkliniek,

University Medical Center Utrecht,

Utrecht, The Netherlands and identification, using standard and papain enzymetreated panels (DiaMed), demonstrated strong positive reactions with all cells. These results were suggestive for the presence of an alloantibody against a highprevalence antigen. Further serologic and genetic analysis revealed that $\mathrm{C} / \mathrm{c}$ and $\mathrm{E} / \mathrm{e}$ antigens were completely absent on the surface of the patient's erythrocytes, indicating the presence of the rare-D-/-D- phenotype [1]. Adsorption and elution studies revealed the presence of anti-C, -E, -e, -Ce, and $-\mathrm{cE}$ alloantibodies and antibodies against the highprevalence antigens of the $\mathrm{RhCcEe}$ polypeptide (anti-Rh17 antibodies) [2]. Furthermore, we identified alloantibodies against $\mathrm{Jk}^{\mathrm{a}}$ and $\mathrm{Le}^{\mathrm{a}}$.

Hemolytic transfusion reactions due to anti- $\mathrm{Le}^{\mathrm{a}}$ are rare [3]. Anti-Rh17 [4] and anti-Jk ${ }^{\mathrm{a}}$ antibodies, however, can lead to massive hemolysis. Therefore, only erythrocytes of donors with the -D- phenotype, negative for $\mathrm{Jk}^{\mathrm{a}}$, could be selected for transfusion. The -D- haplotype is rare, ranging in frequency from 0.0005 in Sweden [5] to 0.0032 in Japan [6], and homozygosity for RHCE-DCE hybrid genes appears to account for several examples of -D- [1]. Worldwide, only two suitable donors were registered. Since the risk of substantial blood loss was low, the patient underwent surgery in the absence of compatible donor erythrocytes. The patient was encouraged to donate autologous blood to be stored at the Sanquin Bank of Frozen Blood (SBFB). In November 2009 , the patient was scheduled for coronary artery bypass graft surgery. It was estimated that, by optimal use of intraoperative cell salvage, the patient would maximally need 1 unit of blood. Five weeks before surgery, the patient's hemoglobin was $15.1 \mathrm{~g} / \mathrm{dL}$, allowing preoperative donation of 2 units of fresh blood. In case of need, frozen units of the SBFB could also be 
thawed. During surgery in December 2009, 1 unit of fresh autologous blood and $400 \mathrm{~mL}$ of cell salvage blood was transfused to the patient. Postoperatively the patient's hemoglobin level was $11.1 \mathrm{~g} / \mathrm{dL}$. He was discharged from the hospital 9 days later.

To date the clinical relevance of the -D- phenotype has been predominantly described in pregnant women, causing mild to fatal hemolytic disease of the newborn $[4,7-10]$. We describe the successful treatment of a patient with recurrent need of transfusions despite the presence of antibodies against the high-prevalence antigens of the $\mathrm{RhCcEe}$ polypeptide combined with anti-Jk ${ }^{\mathrm{a}}$.

Acknowledgments The authors would like to thank Peter Ligthart (Department of Immunohaematology Diagnostic Services, Sanquin Blood Supply, Amsterdam, The Netherlands) for his consultancy.

Conflict of interest The authors declare to hold no conflict of interest with the publication of the results included in this manuscript.

Open Access This article is distributed under the terms of the Creative Commons Attribution Noncommercial License which permits any noncommercial use, distribution, and reproduction in any medium, provided the original author(s) and source are credited.

\section{References}

1. Avent AD, Reid ME (2000) The Rh blood group system: a review. Blood 95:375-387

2. Flegel WA, Wagner FF (2000) Molecular genetics of RH. Vox Sang 78(S2):109-115

3. Henry S, Oriol R, Samuelsson B (1995) Lewis histo-blood group system and associated secretory phenotypes. Vox Sang 69(3):166-182

4. Han KS, Kim HC, Han KS, Shim WS (1997) A case of fatal hemolytic disease of the newborn associated with -D-/-Dphenotype. Am J Perinatol 14:495-497

5. Rasmuson M, Heiken A (1966) Frequency of occurrence of the human Rh complexes $\mathrm{D}(\mathrm{C})(\mathrm{e}), \mathrm{d}(\mathrm{c})(\mathrm{e}), \mathrm{D}-$ and - Nature 212 (5068):1377-1379

6. Okubo Y, Tomita T, Nagao N, Yamaguchi H, Tanaka M (1983) Mass screening donors for -D- and Jk (a-b-) using the Groupamatic-360. Transfusion 23(4):362-363

7. Deitenbeck R, Tutschek B, Crombach G, Stannigel H (1999) Successful management of pregnancy and hemolytic disease of the newborn due to anti- $\mathrm{Hr}_{\mathrm{o}}$ in a woman of the D-phenotype. Transfusion 39:1151-1152

8. Brumit MC, Carnahan GE, Stubbs JR et al (2002) Moderate hemolytic disease of the newborn (HDN) due to anti-Rh17 produced by a black female with an e variant phenotype. Immunohematology 18:40-42

9. Aref K, Boctor FN, Pande S et al (2002) Successful perinatal management of hydrops fetalis due to hemolytic disease associated with D-maternal phenotype. J Perinatol 22:667-668

10. Hirose M, Nakanishi K, Kaku S et al (2004) Fetal hemolytic disease due to anti-Rh17 alloimmunization. Fetal Diagn Ther 19:182-186 